\title{
Building energy consumption modeling at urban scale: three case studies in Europe for residential buildings
}

\author{
Guglielmina Mutani*, Valeria \\ Todeschi \\ of Politecnico di Torino \\ Turin, Italy \\ *name.surname@polito.it
}

\author{
Jérôme Kämpf* \\ of University of Applied Sciences of \\ Western Switzerland \\ Fribourg, Switzerland \\ *Jerome.Kaempf@hefr.ch
}

\author{
Volker Coors*, Matthias Fitzky \\ of Technology University of Applied \\ Sciences \\ Stuttgart, Germany \\ *volker.coors@hft-stuttgart.de
}

\begin{abstract}
In urban contexts, the use of energy in buildings is one of the main causes of greenhouse gas emissions. The reduction of energy-use in buildings could be one of the main drivers to improve the sustainability, livability and quality of urban environment, together with the production of energy from the available renewable sources. To achieve energy sustainability in the most critical high-density urban contexts, it is necessary to optimize: the energy consumptions compatibility of different users; the distribution of heat, for example through the district heating network; the use of all urban spaces, such as building envelopes and urban surfaces, to produce energy from the available renewable sources. The energy models at urban scale are a complex issue as they should be simplified to be applied on a vast territory. Indeed, detailed information are not given at territorial scale and short time of simulation are preferable; however, information should be detailed enough to describe properly the energy consumption of the whole urban environment from building to urban scale. Therefore, energy models should take into account also the urban morphology, people's behavior, social and economic conditions, local and national regulation, and the use of outdoor public spaces. The challenge of this work is to present three different energy-use models, to compare their characteristics and to find the best features of an "optimum" model to analyze and represent energy resources, future scenarios, energy efficiency solutions and best energy policies. The aim is to drive a smarter use of energy, matching it with the available and more efficient energy sources to help also public administrations in defining policies adapted to the real buildings heritage. The urban energy models can also be applied in future climatic scenarios, to evaluate the impact of climate change in the energy demand/supply of buildings, as well as in the potential of retrofit scenarios.
\end{abstract}

Keywords - building energy modeling; 3D city models; enegineering models; GIS-based approach; urban scale; urban morphlogy.

\section{INTRODUCTION}

The Paris Agreement, adopted in 2015, set the specific goal of holding global warming to below $2{ }^{\circ} \mathrm{C}$ compared to pre-industrial levels, and of pursuing efforts to limit warming to $1.5{ }^{\circ} \mathrm{C}$ by 2030 . Under the current policy scenario, buildings account for annual energy-related greenhouse gas
(GHG) emissions of $12.6 \mathrm{Gt}_{\mathrm{CO} 2}$ in 2030 . The $29 \%$ of these GHGs are direct, mainly from space heating and hot water production, and $71 \%$ are indirect, mainly from electric appliances and lighting. Improvements in energy efficiency is an important step to limit the GHG emission for all energy uses [1]. The current European Climate and Energy Policies EU-2020 and EU-2030/2050 are focused on climate changes, energy efficiency and renewable energy sources influencing the energy sector due to a strong and constant political agenda on the road to a sustainable, inclusive, affordable and resilient energy system $[2,3]$. The sustainability of urban environments can be analyzed on multiple dimensions including: environmental, social and economic aspects optimizing the type of human activities and the neighborhood use with energy-consumption and the livability of urban environments. Optimization of energy demand and supply of buildings at urban level could be a good compromise to achieve a sustainable use of energy in a high-energy demand urban context. Then, energy models can help policy makers to plan energy measures in order to improve sustainability and livability in cities $[4,5]$.

The most used actions to improve the environmental sustainability are: reduce energy consumptions and manage the heat distribution, for example through the optimization of the district heating network connected with a cogeneration plant; investigate the best building retrofit solutions for an optimal re-tuning on the buildings uses at district level; decrease GHG emissions maximizing the harvesting of renewable energy sources considering the limited availability of these energy sources in urban context, leading to combine renewable technologies with energy savings measures; increase the livability of urban environment increasing the use of green and reflective materials [6].

Reliable energy end-use data and indicators are very important to represent and monitor the effectiveness of energy efficiency policies, as they help to understand the drivers of energy-use [3]. One of the main issues during the creation of energy consumption models are: the availability, quality, organization, accessibility and sharing of spatial information data (Inspire Directive 2007/2/EC). The European Inspire Directive is trying to identify measures that will address exchange, sharing, access and use of interoperable spatial data 
and spatial data services across the various levels of public authority and across different sectors and countries. Actually, spatial data are organized into different formats, structures and territorial scales. The use of Geographic information systems and spatial data such as building footprints and 3D City Models are fundamental to create a georeferenced database, which contains all the available information at territorial scale $[7,8]$.

According to International Energy Agency [3], energy efficiency improvements for space heating have occurred across IEA countries, mostly through a better thermal insulation of new buildings, improvements in heating equipment efficiencies and overall retrofit of old buildings. Table I shows energy efficiency indicators data of residential buildings heritage for Germany, Italy and Switzerland in the years 2000 and 2015: residential annual consumption EC $[\mathrm{GWh} / \mathrm{y}]$, share of fossil fuels for space heating [\%], number of inhabitants [million], annual consumption per capita or per $\mathrm{m}^{2}$ [EC/inh $\mathrm{kWh} / \mathrm{inh} / \mathrm{y}$ and $\left.\mathrm{EP} \mathrm{kWh} / \mathrm{m}^{2} / \mathrm{y}\right]$, average dwelling surface $\left[\mathrm{m}^{2}\right]$ and average dwelling occupancy [inh/dw]. These results show that energy consumption $\left(\mathrm{EC}_{\mathrm{GL}}\right)$ is considerably decreased with recent energy policies in Germany and Switzerland. In Italy energy consumptions is quite constant considering that the dwelling surfaces decreased but the use of fossil fuel has significantly decreased $(-28 \%)$, showing a more use of renewable sources. Moreover, considering the heating floor surface and the Heating Degree Days (HDD [9]), it is possible to notice similar energy consumptions $\left(\mathrm{kWh} / \mathrm{m}^{2} / \mathrm{y}\right)$ in Italy with 2,500 HDD and in Germany with 3,500 HDD; instead in Switzerland, energy consumption is lower but this result depends on the quota of $\mathrm{m}^{2} /$ inh that in Switzerland is $30 \%$ higher than in Italy and Germany.

In this work, three different energy models were applied to three case studies in Europe the cities of: Turin (IT), Essen (DE) and Geneva $(\mathrm{CH})$.

TABLE I. RESIDENTIAL BUILDINGS: ENERGY EFFICIENCY INDICATORS

\begin{tabular}{|c|c|c|c|c|c|c|c|c|}
\hline \multirow{2}{*}{ 己ٍ } & \multirow[t]{2}{*}{ Year } & $\mathbf{E C}_{\mathbf{G L}}$ & $\begin{array}{c}\text { Fossil } \\
\text { fuel }\end{array}$ & Inh. & $\begin{array}{c}\text { EC }_{G L} \\
\text { per } \\
\text { capita }\end{array}$ & $\begin{array}{c}\text { Dw } \\
\text { surface }\end{array}$ & $\begin{array}{c}\text { Dw } \\
\text { occup. }\end{array}$ & $\mathbf{E P}_{\mathrm{GL}}$ \\
\hline & & $\begin{array}{c}\text { GWh } 10^{9} \\
\text { Wh }\end{array}$ & $\%$ & $10^{6}$ & $\begin{array}{c}\text { kWh/ } \\
\text { inh }\end{array}$ & $\mathbf{m}^{2}$ & $\begin{array}{c}\text { Inh/ } \\
\text { dw }\end{array}$ & $\begin{array}{c}\mathbf{k W h} / \\
\mathbf{m}^{2} / \mathbf{y}\end{array}$ \\
\hline \multirow{2}{*}{ DE } & 2000 & 718.1 & 82 & 81 & 8888.9 & 85 & 2.3 & 240.5 \\
\hline & 2015 & 620.3 & 81 & 82 & 7500.0 & 96 & 2.1 & 164.1 \\
\hline \multirow{2}{*}{ IT } & 2000 & 320.8 & 93 & 57 & 5555.6 & 96 & 2.6 & 150.5 \\
\hline & 2015 & 378.3 & 67 & 61 & 6111.1 & 93 & 2.5 & 164.3 \\
\hline \multirow{2}{*}{$\mathrm{CH}$} & 2000 & 65.6 & 78 & 7 & 9166.7 & 119 & 2.3 & 177.2 \\
\hline & 2015 & 64.4 & 69 & 8 & 7777.8 & 129 & 2.3 & 138.7 \\
\hline
\end{tabular}

The energy models presented in this work are:

(A) A GIS-based tool for the city of Turin developed with bottom-up and top-down approaches; the use of a GIS tool with the Technical Map of the City of Turin and the Digital Terrain Model were essential to overlay the different data and to be able to perform multi-scale and multi-level analyses on buildings consumption.

(B) A 3D energy city model applied to the case study of Essen with the use of CityGML and the cadaster database; the 3D city model allowed the analysis on the real geometry of each building, including in particular the heated volume and façade/roof orientations.
(C) An engineering tool, CitySim to estimate the buildings energy consumption at the neighborhood scale for some districts of the City of Geneva; this analysis compares different districts with various urban form, solar exposure, outdoor spaces and material characteristics of the urban surfaces, to evaluate their impact on buildings energy performance.

\section{MATERIALS AND METHOD}

The proposed methodology defines the buildings energy model at urban scale with an iterative process subdivided in the following steps:

- The analysis of the main energy-use driven variables to develop simplified energy models of buildings at the urban/district level. Some variables can be defined as fundamental, while other variables can improve the accuracy of the results. Furthermore, also the different scale of the building data should influence the accuracy of the results (Table II). In literature, space heating energy consumption is mainly influenced by climate, period of construction, buildings' compactness and surrounding (urban) context [10].

- The definition of a procedure to harmonize data from different sources and with different scales. This step is useful for data collection and representation of the three case studies.

- The evaluation of the existing energy-use models at urban scale (e.g. Turin, Essen and Geneva models) for the optimizations of the models themselves; the interaction and the complementary use of bottom-up, top-down, statistical, and engineering (e.g. CitySim) energy models was assessed.

- The use of existing models to identify the more effective retrofit measures on existing buildings.

- The use of existing models to evaluate the available renewable energy sources and then the potential of renewable energy technologies at urban scale.

- The application of the analysed urban models on different cities, with different buildings' stock, users, climate and energy sources with the aim to test the capabilities of the models to adapt to different conditions, assessing the demonstration of their replicability potential.

Table II shows the input data used to create energy consumption models, in particular there are:

Data of buildings from municipal technical maps and/or cadaster at building scale (obligatory data):

- Buildings characteristics: type of users, number of buildings, number of floors or building height, period of construction, surface to volume ratio, gross heated volume, net heated surface.

- Census sections data: people occupancy, central or autonomous heating systems, type of fuels, inhabitants socio-economic data.

- Microclimatic conditions: weather stations data (HDD at $20^{\circ} \mathrm{C}$ and monthly air temperatures).

Data of measured energy-needs $\mathrm{EP}_{\underline{\mathrm{H}}}$ or $\mathrm{EP}_{\mathrm{GL}}$ at building scale from energy distribution companies (obligatory data):

- Real space heating consumption and gross or real net heated volume of the buildings; data about more than 
2,000 buildings were collected for at least three consecutive heating seasons (2009-2016 data).

Data of measured energy-needs $\mathrm{EP}_{\mathrm{H}}$ or $\mathrm{EP}_{\mathrm{GL}}$ at municipal or urban scale (obligatory data):

- Measured annual energy consumption for space heating and heated volumes for all sectors and/or type of buildings at municipal scale (i.e. from the Sustainable Energy Action Plans).

Urban variables at block of buildings scale from ISTAT census database and municipal technical maps (optional data):

- Building density, building height, building coverage ratio, relative buildings height, aspect ratio, solar exposition, main orientation streets, albedo of outdoor surfaces.

Socio-economic variables of inhabitants at block of buildings scale from ISTAT census database (optional data):

- Number of inhabitants, number of families and family members, percentage of foreigners, gender, age, income, employment rate.

TABLE II. INPUT DATA USED TO CREATE ENERGY MODELS

\begin{tabular}{|c|c|c|c|}
\hline \multirow[b]{2}{*}{ Input data } & \multicolumn{3}{|c|}{ Energy Consumption Models } \\
\hline & $\begin{array}{l}\text { (A) GIS-based } \\
\text { model }\end{array}$ & (B) CityGML 3D model & (C) CitySim tool \\
\hline $\begin{array}{l}\text { Building } \\
\text { scale }\end{array}$ & $\begin{array}{l}\text { - Geometrical } \\
\text { characteristic: } \\
\text { height, S/V ratio, } \\
\text { gross heated } \\
\text { volume, net heated } \\
\text { surface } \\
\text { - Year of } \\
\text { construction } \\
\text { - Type of users } \\
\text { - Nearest weather } \\
\text { station data } \\
\text { (monthly air } \\
\text { temperatures and } \\
\text { HDD at } 20^{\circ} \mathrm{C} \text { ) }\end{array}$ & $\begin{array}{l}\text { - Geometrical } \\
\text { characteristic: 3D } \\
\text { building Geometry in } \\
\text { LoD1 (and LoD2), } \\
\text { azimuth and tilt of the } \\
\text { roof and wall surfaces, } \\
\text { height, gross and heated } \\
\text { volume, S/V ratio, net } \\
\text { heated floor area surface } \\
\text { - Year of construction } \\
\text { - Type of users (ALKIS } \\
\text { code) } \\
\text { - Nearest weather } \\
\text { station data }\end{array}$ & $\begin{array}{l}\text { - Cadastral } \\
\text { information (2D or } \\
\text { 3D) } \\
\text { - Statistical } \\
\text { information } \\
\text { regarding the } \\
\text { buildings (age, } \\
\text { refurbishment, use) } \\
\text { - Weather station } \\
\text { data (hourly direct, } \\
\text { diffuse irradiance, } \\
\text { air temperature, } \\
\text { humidity, } \\
\text { nebulosity) }\end{array}$ \\
\hline $\begin{array}{l}\text { Bottom-up } \\
\text { approach }\end{array}$ & $\begin{array}{l}\text { Measured } \mathrm{EP} \text { at } \\
\text { building scale: } \\
\text { annual energy } \\
\text { consumption of } \\
\text { more than } 2,000 \\
\text { buildings for } 2 \text { or } 3 \\
\text { consecutive seasons }\end{array}$ & $\begin{array}{l}\text { Detailed measured } \\
\text { heating consumption for } \\
6 \text { buildings (monthly } \\
\text { and annual energy } \\
\text { consumption) }\end{array}$ & $\begin{array}{l}\text { Calibration of the } \\
\text { uncertain simulation } \\
\text { parameters by } \\
\text { optimisation with } \\
\text { consumption } \\
\text { measurements }\end{array}$ \\
\hline $\begin{array}{l}\text { Top-down } \\
\text { approach }\end{array}$ & $\begin{array}{l}\text { Measured EPGL at } \\
\text { urban scale: annual } \\
\text { energy consumption } \\
\text { for all sectors and/or } \\
\text { for type of buildings } \\
\text { at municipal scale }\end{array}$ & $\mathrm{n} / \mathrm{a}$ & $\begin{array}{l}\text { Sum of the energy } \\
\text { consumption at the } \\
\text { building scale }\end{array}$ \\
\hline Simulation & $\begin{array}{l}\text { Spatial } \\
\text { representation of } \\
\text { space heating } \\
\text { consumption with a } \\
\text { GIS tool }\end{array}$ & Simstadt simulation & $\begin{array}{l}\text { 3D representation of } \\
\text { the space } \\
\text { heating/cooling with } \\
\text { false color images }\end{array}$ \\
\hline
\end{tabular}

\section{A. GIS-based model}

The GIS-based model developed for the city of Turin was made to evaluate: (i) the spatial distribution of energy consumptions, (ii) the energy saving potential with the existing energy policies or future scenarios and (iii) the influence of the surrounding urban context on energy consumption.

For the City of Turin, a GIS-based assessment was developed to characterize the energy performance of the buildings heritage from the comparison of bottom-up and topdown approaches [4, 11]. Generally, building energy consumption models can be distinguished into top-down, bottom-up and hybrid modeling approaches. The top-down approach uses regression to find the correlation between building energy consumption and top-level variables (climate conditions, socio-economic trends, urban morphology, ...). The bottom-up approach includes the classification of buildings in archetypes and requires a detailed description of the buildings stock. Moreover, hybrid approach uses also engineering tools to evaluate different conditions than the real ones influencing energy consumptions.

The application of these models with a GIS tool consent to estimate the spatial distribution of energy-uses on a territory, based on real energy consumption data and buildings characteristics. In this work, the application of buildings energy models on the municipal territory of Turin was achieved with a Geographic Information System tool (ArcGIS 10.5.1). With the support of GIS tool, an updated database was created with all georeferenced information available at different scales and on different levels. The main georeferenced spatial data necessary to create a GIS-based energy model are shown in Table II. The aim of this GISbased approach is to plan energy efficiency and low emissions policies giving a priority on the more effective retrofit interventions and renewable energy technologies. With the support of energy demand and supply models at territorial scale, the energy savings and low emissions models can be created considering the adoption of different energy policies (from the existing, to future more effective scenarios [6]) to reach climate and energy targets.

\section{B. City GML $3 D$ model}

The calculation of the heat demand takes place within Simstadt $[12,13]$. First, the corresponding 3D city model is imported into the software. This step checks whether the file complies with the current guidelines for CityGML. The total number of houses in the data set is also counted.

In the next step, the attributes of the buildings identified are supplemented with further attributes that are important for calculating the heating requirement. The footprint area, then the accuracy level (divided into LOD1 to LOD4) and the respective refurbishment status (can also be listed directly in the data set as an attribute) are derived from the existing attributes. In addition to the metadata mentioned, other geometry-related attributes are calculated. These attributes include the wall inclinations and orientations, the respective volumes, the area available per floor and the total heated area per house. From the totality of these parameters a building classification can be derived, which is used in its form only in Germany. A distinction is made between 5 different building classes, according to the Institute IWU (German Institute for residential and environmental affairs): Single Family House (EFH); House built in a Row (RH); Multi Family House (MFH); Big Multi Family House (GMH); Skyscraper (HH).

Then, a library of building physics parameters is imported into the calculation process. With the information about the year of construction and the classification of the house type, this XML-library can be used to link building physical parameters with the buildings to be calculated here. The most important of these parameters is the heat transfer coefficient. This value indicates how much heat is emitted to the outside by each building part. It is given in $\mathrm{W} / \mathrm{m}^{2} / \mathrm{K}$ (heating energy in 
Watt, Surface of the building parts in $\mathrm{m}^{2}$, Difference of Temperature inside/outside in Kelvin).

After the assignment of the heat transfer coefficients to each building part, a second XML library is taken into account. This library is used to assign usage-specific parameters to buildings. Depending on the use of a building, the duration of daily use varies, which is reflected in the type of heat circulation and the average indoor temperature.

In order to include the outdoor temperature into the calculation of the heating demand, the local average outdoor temperature as found in the database of the software called "INSEL" is used. Data for the radiation of the sun onto the outer wall surfaces are also extracted from the database of the INSEL software and integrated into the simulation model. Here the respective wall inclination is regarded and a factor of each wall's radiation is calculated. By the sum of the imported and generated attributes per house, a calculation of the heating demand in annual or monthly form is now possible $[14,15]$.

\section{CitySim engineering tool}

CitySim is an urban performance simulation engine developed at EPFL that comprises a solver module (CitySim Solver) as well as a graphical user interface (CitySim Pro). It focuses on the energy flows of multiple simplified building models and their interdependent relationship with their urban climate [16]. CitySim includes building thermal, urban radiation, occupant behaviour, and plant/equipment models integrated as a single simulation engine. CitySim simulates multiple buildings up to district scale using simplified models to achieve a compromise between modelling accuracy, computational overheads, and data availability.

The tool itself can potentially be applied to simulate the on-site energy demand for heating and cooling the buildings. By adopting energy saving measures encouraged by city representatives, CitySim can evaluate the quantified impact of such measures within our current climate or even their resilience to climate change [17].

The advantage of such City Energy Simulation engine lies in the consideration of the urban context: shading and interreflexions within urban canyons. Those aspects are specifically important in dense urban areas when tending to low-energy buildings (future development scenarios) that depend heavily on solar resources [18].

\section{III.}

\section{CAse Studies}

In this section the description and the main characteristics of the three case studies are presented. Table III shows, for each case study, information about the number of inhabitants, the residential buildings (number of buildings and their gross volume), the Heating Degree Days, the main year of construction, the $\mathrm{S} / \mathrm{V}$ ratio (median value).

TABLE III. CHARACTERISTICS OF THE THREE CASE STUDIES

\begin{tabular}{|c|c|c|c|c|c|}
\hline City & Inhabitants & $\begin{array}{c}\text { Residential } \\
\text { buildings }\end{array}$ & $\begin{array}{c}\text { HDD at } \\
\mathbf{2 0}^{\circ} \mathbf{C}\end{array}$ & $\begin{array}{c}\text { Main year of } \\
\text { construction } \\
\text { n. buildings }\end{array}$ & $\begin{array}{c}\mathbf{S} / \mathbf{V}_{\text {median }} \\
\mathbf{m}^{\mathbf{2}} / \mathbf{m}^{\mathbf{3}}\end{array}$ \\
\hline Turin (IT) & $\begin{array}{c}882,523 \\
(2017, \text { ISTAT) }\end{array}$ & $\begin{array}{c}44,803 \\
\left(164 \mathrm{Mm}^{3}\right)\end{array}$ & $\begin{array}{c}2,648(\mathrm{UNI} \\
10349-3)\end{array}$ & $\begin{array}{c}1961-70 \\
24,156 \text { build. }\end{array}$ & 0.51 \\
\hline $\begin{array}{c}\text { Essen (DE) } \\
{[19,20]}\end{array}$ & $\mathrm{n} / \mathrm{a}$ & 2,152 & $\mathrm{n} / \mathrm{a}$ & $\begin{array}{c}\text { Before } 1918 \\
1,234 \text { build. }\end{array}$ & 0.85 \\
\hline $\begin{array}{c}\text { Jonction/ } \\
\text { Geneva (CH) }\end{array}$ & 48,000 & $\begin{array}{c}806 \\
(5.19 \mathrm{Mm} 3)\end{array}$ & $\mathrm{n} / \mathrm{a}$ & $\begin{array}{c}\text { Before } 1919 \\
194 \text { build. }\end{array}$ & 0.28 \\
\hline
\end{tabular}

\section{A. City of Turin (Italy)}

The City of Turin is located in North-Western part of Italy with a temperate climate and in the last 10 years the population was approximately constant $( \pm 1 \%)$; the population resident in 1991 was equal to 979,839 with a historical minimum in 2002 (866,134 inh). Per capita income grew from 2000 to $2007-2008$, then decreased slightly after 2008 due to the economic crisis [21].

In Turin there are 58,970 heated buildings equal to 232 $\mathrm{Mm}^{3}$, of which about $76 \%$ are residential. The residential sector consists mainly of big and compact condominiums with a surface to volume ratio (S/V) minor than $0.45(39 \%)$; the buildings heritage is quite old with the $57 \%$ of the residential buildings built before 1960 and the $80 \%$ before 1970 (before the first Italian Law 373/1976 on energy savings in buildings); only $15 \%$ was built in 1970-2000 and only $2 \%$ after 2006 [4].

Electricity and thermal energy consumptions of Turin depend mainly on climate conditions, the number of inhabitants, and on socio-economic conditions. In particular, thermal consumption depends on HDD at $20^{\circ} \mathrm{C}$ and on per capita earning, while electricity consumption is more constant and depends more by the number of inhabitants. Thermal consumption represents $80 \%$ of total energy consumption (and electricity 20\%). The residential buildings have a major impact on total consumptions with the $59 \%$; relating to GHG emissions, the residential sector affects for the $52 \%$ and the trend of GHG emissions follows the trend of energy consumption [21].

The heat energy-use of the Turin buildings is quite high; about its $55 \%$ is covered by the district heating network. To increase Turin's energy sustainability, the optimization of the energy consumption of different sectors is crucial. With the improvement of the district heating network, substantial environmental benefits can still be reached with retrofit measures and the construction of new nZEB and nZE-districts, in line with the sustainable urban development of Turin [22].

\section{B. City of Essen (Germany)}

This city is located in western Germany, more specifically in the federal state North-Rhine Westphalia. The climate in Essen can be classified as moderate.

According to the Governmental Agency for statistics there are 590,099 residents currently living in Essen. Those are distributed into 87,722 buildings with residential usage (year 2017). A building is counted as residential if at least $50 \%$ of it's usable space is used for residential purposes [23]. These residential buildings mainly consist of multiple rentable apartments. Most of the houses were built between 1949 and 1978 with a share of $46.7 \%$ of all residential buildings. The next biggest group is settled between the years 1919 to 1948 with $17.4 \%$. Buildings which were built between 1996 up to the current date only account $9.1 \%$ to the total [24].

\section{A district of Geneva (Switzerland)}

The City of Geneva is located in the western Frenchspeaking part of Switzerland. With a moderate climate, the city is situated where the Rhône river exits Lake Geneva. The municipality counts about 200,000 inhabitants over about 16 $\mathrm{km}^{2}$. 
Administratively, the urban region is subdivided into eight districts, 4 on the left bank of the river and 4 on the right bank. The Jonction district is a place where rivers Rhône and Arve join each other, making a part of the district forming a triangle. The district is mainly composed of buildings built before 1919, but has also a brand new eco-district in its heart.

The zone studied in the Jonction district is mainly residential and covers about 800 buildings. The biggest share is built before 1919 with $24 \%$, followed by buildings built between 1986 and 1990 with $21 \%$ and $17 \%$ built between 1919 and 1945. Recent buildings (built after 2000) cover only a few percent of the buildings in the area.

\section{IV.}

\section{RESULTS AND DISCUSSION}

\section{A. GIS-based model applied to the City of Turin (IT)}

In relation to the steps identified in paragraph IIA on the methodology, the GIS-based assessment has been applied to the City of Turin:

(i) Bottom-up models operate at building scale for the building archetypes and to create this models more than 2,000 space heating energy consumption of residential $(88 \%)$ and non-residential $(12 \%)$ buildings were georeferenced. The energy consumption data were normalized to a typical heating season (from $15^{\text {th }}$ October 2011 to $15^{\text {th }}$ April 2012) considering 5 weather stations in the City of Turin with the following $\operatorname{HDD} 2011-12$ : Alenia $2,369^{\circ} \mathrm{C}$; Reiss Romoli 2,356 ${ }^{\circ} \mathrm{C}$; Via della Consolata $2,221^{\circ} \mathrm{C}$; Unito $2,313^{\circ} \mathrm{C}$; Polito $2,137^{\circ} \mathrm{C}$. Different types of residential buildings were subdivided into homogeneous groups (the buildings archetypes) by end-use and geometrical characteristics. For every homogeneous group, a statistical analysis was performed in order to evaluate the type of statistical distribution of energy consumption data (i.e. normal, lognormal or gamma distribution). From this analysis, a simplified equation of space heating energy-use intensity $\left(\mathrm{kWh} / \mathrm{m}^{2} / \mathrm{y}\right.$ or $\left.\mathrm{kWh} / \mathrm{m}^{3} / \mathrm{y}\right)$ was defined as a function of the period of construction and the surface to volume ratio of the buildings [4]. With a GIS-based tool, this energy-use intensity was applied to each building and the energy consumption at urban level were evaluated knowing the heated volume (for each building). The accuracy of the models depends by the reliability of the databases and the large amount of data missing; a correction coefficient of 1.02 was applied to the simplified energy-use intensity models of buildings archetypes to have a good correspondence with the results of the topdown energy model at municipal scale [4].

(ii) The energy saving potential have been evaluated with different energy efficiency models. Fig. 1 shows for each buildings' period of construction, the current, standard and advanced energy performance $\mathrm{EP}_{\mathrm{GL}}$ of the apartments in Turin. The consumptions are quite constant until 1980 then decrease thanks to the Italian energy policies. These trends derive from a statistical analysis on 103,742 Energy Performance Certificates for residential buildings [6]. With the use of different energy retrofit models (current, standard and advanced) is it possible to evaluate with a GIS-based assessment the energy savings on the real built environment. Similar results have been obtained for the other buildings archetypes.

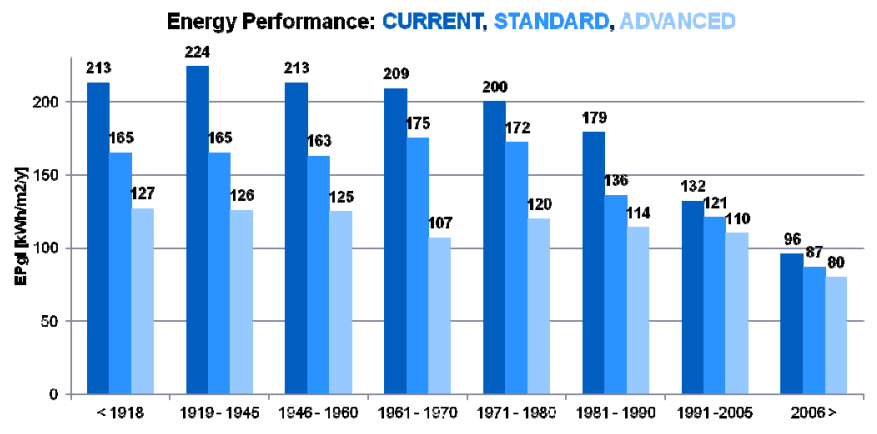

Fig. 1. Energy saving model: energy performance trend for the City of Turin.

(iii) The influence of the surrounding context has been evaluated considering the microclimate variations in the different areas of Turin using the data of the weather stations in the city and taking into account the following differences concerning urban characteristics: buildings density, solar exposition, the average albedo coefficient of urban surfaces and the presence of vegetation and water with the NDVI index [11]. With the support of a GIS tool, spatial analyses were made in order to identify 15 homogenous zones, considering the same building archetypes (with the same period of construction, compactness and socio-economic variables) with different microclimate conditions and urban contexts (Fig. 2). For each homogenous zone, the impact of the urban context on the energy consumption of buildings has been investigated with a linear regressions model. In particular, for residential buildings, in order to analyze the influence of urban context variables on the thermal energy consumption, two linear regression models have been calibrated considering the two main period of constructions 1919-45 and 1961-70:

$$
\begin{aligned}
& E P_{G L}=\mathrm{I}+\alpha_{1} \cdot S / V+\alpha_{2} \cdot B C R+\alpha_{3} \cdot H / H_{a v g}+\alpha_{4} \cdot H / W+\alpha_{5} \cdot M O S+ \\
& +\alpha_{6} \cdot A+\alpha_{7} \cdot N D V I+\alpha_{8} \cdot L S T+\varepsilon
\end{aligned}
$$

where: I is intercept and $\varepsilon$ is the error between the energy consumption data and the results of the linear regression model.

Table IV shows the characteristics of the different 15 homogenous zones: prevalent period of construction [-]; average surface to volume ratio $(\mathrm{S} / \mathrm{V})\left[\mathrm{m}^{-1}\right]$; thermal energy performance, $\mathrm{EP}_{\mathrm{GL}}\left[\mathrm{kWh} / \mathrm{m}^{3} / \mathrm{y}\right]$; Building Coverage Ratio (BCR) [-]; relative height $\left(\mathrm{H} / \mathrm{H}_{\mathrm{avg}}\right.$, $)[-]$; height to distance ratio (H/W) [-]; Main Orientation Street (MOS) varying from 0 to 1 , with 0 corresponding to the North-South direction and 1 to West-East direction [-]; Albedo (A $\mathrm{A}_{\mathrm{NIR}}$ Near Infra-Red) [-]; Land Surface Temperature (LST) $\left[{ }^{\circ} \mathrm{C}\right]$; and Normalized Difference Vegetation Index (NDVI) [-]. To evaluate $A_{N I R}$, LST and NDVI, satellite Landsat 7 images were used at November $24^{\text {th }} 2011$ at 10 a.m. (with a cloud cover of $4 \%$ ) [25].

For buildings built before 1918 (homogeneous groups 5 and 7) the $\mathrm{S} / \mathrm{V}$ is directly proportional to energy consumption $\left(\mathrm{EP}_{\mathrm{GL}}\right)$, the same trend occurs for buildings built in 1919-45 (groups 1, 4, 10, 11 and 14), with the exception of zone 14 due to the influence of microclimate. In addition, the NDVI index is lower for groups 4 and 10 (there are values less than 0 ), this indicates the presence of built-up areas and also the BCR is higher than the other zones; the number of inhabitants is about 4,000 , while in the other areas the average number of 
inhabitants is 500. For buildings constructed between 1961

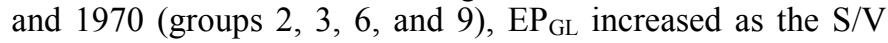
increased, with the exception of zone 13 with lower air temperatures. In general, considering buildings built before 1970 there are higher $\mathrm{EP}_{\mathrm{GL}}$ where the components per family are greater than 2 (groups 3, 5, 13 and 14). Moreover, in the areas in the city center (groups 5, 4 and 10), the inhabitants have a higher income (average value equal to 20,293€); the most critical areas are those with an average income of 12,983 $€$, located far from the city center (groups 7, 12, 13 and 14). Finally, buildings built after 2001 (groups 12 and 15) have lower energy consumption thanks to the recent Italian laws one energy savings and low emissions technologies; in these areas the average income quite low of $13,890 €$ because of the distance from the city center.

TABLE IV. RESIDENTIAL BUILDINGS CHARACTERISTICS’ OF 15 HOMOGENOUS ZONES OF TURIN

\begin{tabular}{|c|c|c|c|c|c|c|c|c|c|c|}
\hline $\begin{array}{l}\stackrel{\mathscr{U}}{\Xi} \\
\stackrel{0}{N}\end{array}$ & 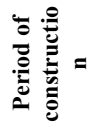 & $\begin{array}{l}i_{\infty}^{\prime} \\
\sum_{\infty}\end{array}$ & $\underset{\overbrace{}}{\tilde{0}}$ & Ex & $\hat{z}$ & 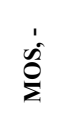 & $\frac{\dot{E}}{4}$ & 家 & ט. & 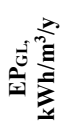 \\
\hline 1 & 1919-45 & 0.57 & 0.20 & 1.02 & 0.28 & 0.69 & 0.12 & 0.08 & 6.99 & 44.3 \\
\hline 2 & 1961-70 & 0.42 & 0.23 & 1.01 & 0.27 & 0.65 & 0.12 & 0.06 & 5.12 & 34.9 \\
\hline 3 & 1961-70 & 0.75 & 0.39 & 1.05 & 0.35 & 0.30 & 0.11 & 0.09 & 6.78 & 39.1 \\
\hline 4 & $1919-45$ & 0.51 & 0.40 & 0.97 & 0.52 & 0.50 & 0.09 & -0.02 & 6.41 & 38.7 \\
\hline 5 & $>1918$ & 0.74 & 0.16 & 0.96 & 0.27 & 0.40 & 0.11 & 0.08 & 7.29 & 42.6 \\
\hline 6 & 1961-70 & 0.45 & 0.37 & 0.97 & 0.51 & 0.64 & 0.10 & 0.00 & 7.01 & 37.1 \\
\hline 7 & $>1918$ & 0.42 & 0.23 & 1.15 & 0.29 & 0.05 & 0.11 & 0.05 & 7.33 & 39.8 \\
\hline 8 & 1946-60 & 0.41 & 0.28 & 1.01 & 0.62 & 0.65 & 0.11 & 0.03 & 7.05 & 33.3 \\
\hline 9 & 1961-70 & 0.52 & 0.48 & 0.95 & 0.57 & 0.50 & 0.10 & 0.01 & 7.39 & 38.2 \\
\hline 10 & 1919-45 & 0.56 & 0.49 & 0.95 & 0.60 & 0.60 & 0.10 & -0.02 & 8.10 & 40.6 \\
\hline 11 & $1919-45$ & 0.69 & 0.35 & 1.02 & 0.41 & 0.36 & 0.12 & 0.08 & 5.64 & 41.9 \\
\hline 12 & 2001-05 & 0.81 & 0.22 & 1.01 & 0.47 & 0.21 & 0.13 & 0.12 & 6.82 & 32.6 \\
\hline 13 & 1946-60 & 0.34 & 0.12 & 1.76 & 0.25 & 0.37 & 0.11 & 0.06 & 6.33 & 39.2 \\
\hline 14 & $1919-45$ & 0.45 & 0.12 & 0.90 & 0.24 & 0.76 & 0.14 & 0.11 & 6.47 & 50.0 \\
\hline 15 & 2001-05 & 0.59 & 0.21 & 1.02 & 0.34 & 0.32 & 0.12 & 0.07 & 6.08 & 30.1 \\
\hline
\end{tabular}

TABLE V. COEFFICIENTS OF LINEAR REGRESSION MODELS

\begin{tabular}{|c|c|c|c|c|c|c|c|c|c|c|}
\hline 离 & 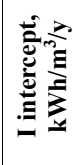 & $\underbrace{\frac{\pi}{2}}_{\frac{\pi}{8}}$ & 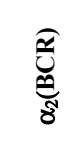 & 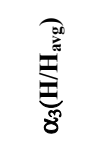 & $\sum_{\text {J }}^{8}$ & 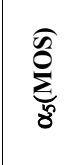 & 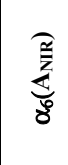 & 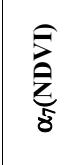 & $\underset{8}{\stackrel{6}{0}}$ & 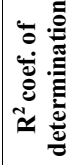 \\
\hline \multicolumn{11}{|c|}{ Period of construction 1919-45 } \\
\hline \multicolumn{2}{|c|}{$\begin{array}{l}\text { Correlation } \\
\text { coefficient }\end{array}$} & -0.44 & -0.89 & -0.49 & -0.86 & 0.70 & 0.89 & 0.85 & -0.14 & - \\
\hline M1 & 55.54 & 19.90 & 0.22 & -27.18 & -0.47 & 24.56 & 7.68 & 24.32 & -2.02 & 0.98 \\
\hline M2 & 35.17 & 0.00 & -19.17 & 0.00 & -7.43 & 0.00 & 11.85 & 23.64 & 2.26 & 0.86 \\
\hline M3 & 45.46 & - & -14.70 & - & -1.74 & - & 5.09 & 21.08 & - & 0.77 \\
\hline \multicolumn{11}{|c|}{ Period of construction 1961-70 } \\
\hline \multicolumn{2}{|c|}{$\begin{array}{l}\text { Correlation } \\
\text { coefficient }\end{array}$} & 0.82 & 0.84 & 0.11 & 0.46 & -0.84 & -0.48 & 0.03 & 0.83 & - \\
\hline M1 & 0.95 & 0.02 & 9.05 & 30.47 & 8.06 & -2.03 & -1.91 & 0.52 & 0.08 & 1.00 \\
\hline M2 & 28.59 & 6.28 & 4.44 & - & - & -0.98 & - & - & 0.64 & 1.00 \\
\hline M3 & 29.08 & 8.05 & 10.10 & - & - & 0.18 & - & - & - & 0.99 \\
\hline
\end{tabular}

In Table $\mathrm{V}$ three linear regression models are presented for two period of construction 1919-45 and 1961-70: the first models (M1) consider all variables, the second ones (M2) consider only the more correlated variables and the third ones (M3) are without the LST. It is possible to observe that urban characteristics (i.e. H/W, A, NDVI) are more influencing the energy consumptions of old buildings (1919-45) with heavy structures and a more thermal inertia. The building coverage ratio $\mathrm{BCR}$ (and urban density) is always influencing the $\mathrm{EP}_{\mathrm{GL}}$.
While, buildings characteristics, as the $\mathrm{S} / \mathrm{V}$, influence $\mathrm{EP}_{\mathrm{GL}}$ of buildings built in 1961-70. The correlation coefficients measure a degree of influence between the dependent variable $\mathrm{EP}_{\mathrm{GL}}$ and independent variables; the coefficient of determination $\mathrm{R}^{2}$ shows how much of the variation of $\mathrm{EP}_{\mathrm{GL}}$ can be explained by the linear regression models.

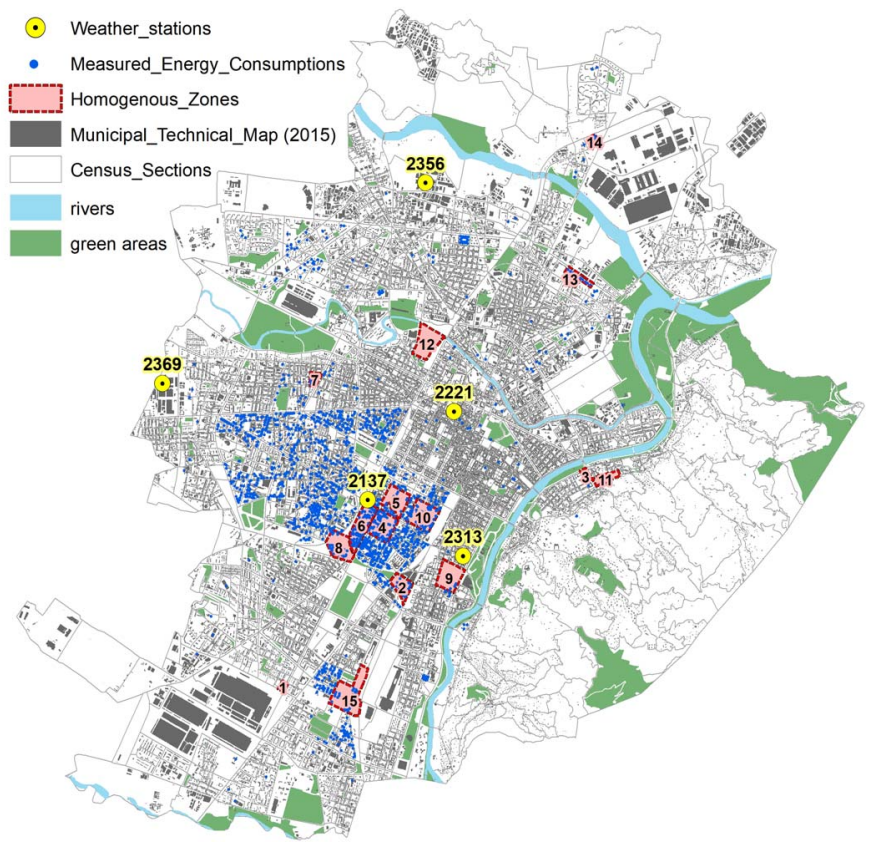

Fig. 2. GIS-based model: identification of 15 homogeneous zones, 5 weather stations with their HDD at $20^{\circ} \mathrm{C}$ (in 2011-12) and more than 2,000 buildings with the monitored energy consumptions for $2 / 3$ consecutive heating seasons.

These linear regressions models are very used in urban planning as compensative methods because, changing one or more variables, the effects can be evaluated immediately.

Then, the use of these GIS-based energy performance models could be also useful to evaluate urban policies for future development as the reuse of existing buildings and empty spaces, typical issue of post-industrial cities like Turin. With the use of the GIS-based assessment, an evaluation of energy consumptions after the reuse of ex-industrial areas and empty residential buildings have been performed in Turin. Of course, the reuse of empty spaces will cause an energy consumption increase with the relative GHG emissions. Fig. 3 shows the space heating energy consumption before and after the reuse of residential sector and of total sector (residential buildings plus empty industrial spaces).

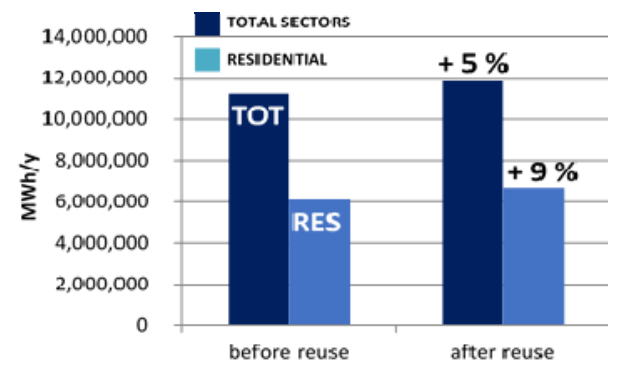

Fig. 3. Space heating energy consumption [MWh/year] before and after the reuse considering the total sector and the residential one. 


\section{B. A CityGML 3D model applied to the City of Essen (DE)}

The sample dataset which has been used to show calculation results using the Software "Simstadt" is coming from the City Essen [20]. In a previous research called "WeBest" the CityGML methodology with the use of the Software Simstadt and different refurbishment scenarios have been tested. The data which came to use is existing in LOD2.

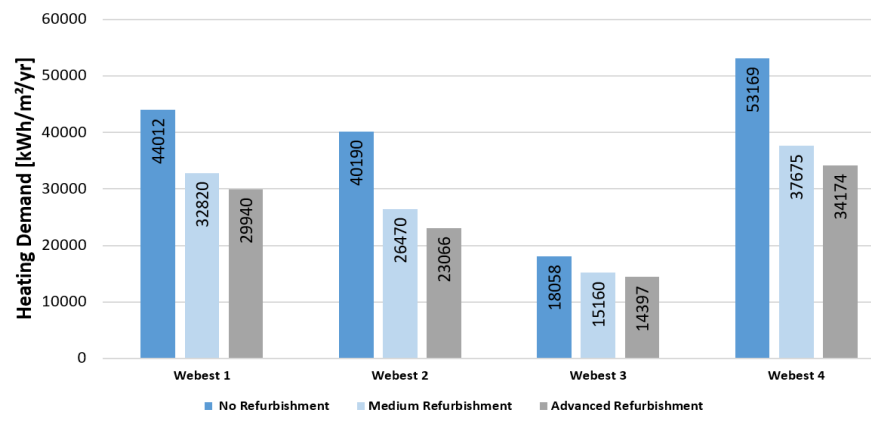

Fig. 4. "Webest" Essen data with refurbishment scenarios.

Fig. 4 shows the distribution of the heat demand mean values in 4 different districts of the 3D City model as used in the project "Webest" [19]. It can clearly be seen that various levels of refurbishment have been taken into account in the software, the values for the heating consumption become better the more comprehensive the refurbishments are. The division of the CityGML File into districts has been made to separate between different construction periods (Table VI).

TABLE VI. NUMBER OF RESIDENTIAL BUILDINGS CONSIDERING THE DISTRICT AND THE CONSTRUCTION PERIOD

\begin{tabular}{|l|l|l|}
\hline District number & Construction period & Number of buildings \\
\hline WeBest 1 & Until 1918 & 1,234 \\
\hline WeBest 2 & $1949-1959$ & 1,189 \\
\hline WeBest 3 & After 2004 & 477 \\
\hline WeBest 4 & $1970-1977$ & 410 \\
\hline
\end{tabular}

The Figs. 5 and 6 show an online 3D visualization of the values calculated in Simstadt for space heating consumption. The legend shows a color coding for each heating consumption $\left[\mathrm{kWH} / \mathrm{m}^{2} / \mathrm{y}\right]$ that is divided as follows: blue 0 50; green 50-100; yellow 100-150; orange 150-200; red >200; grey "invalid processing". As it can be seen in the 3D Visualizations, a higher level of refurbishment means that the simulated heating consumption of each building will be lowered.

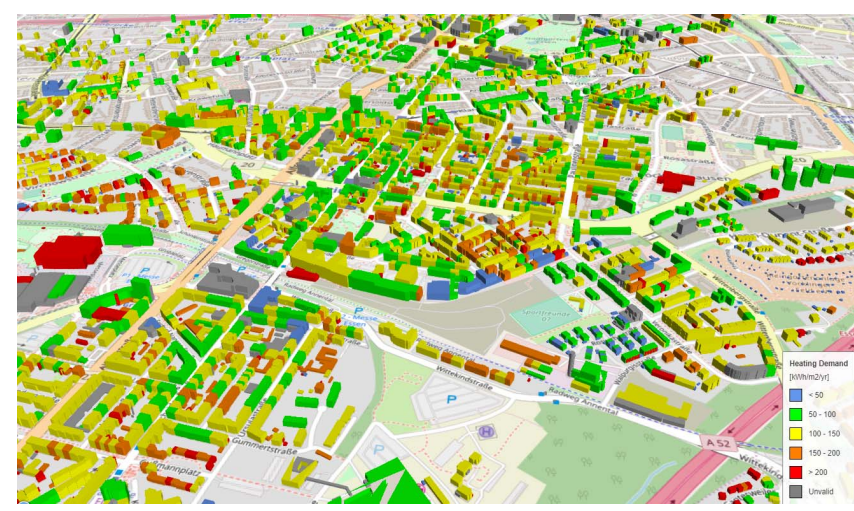

Fig. 5. City of Essen heating consumption with No Refurbishment.

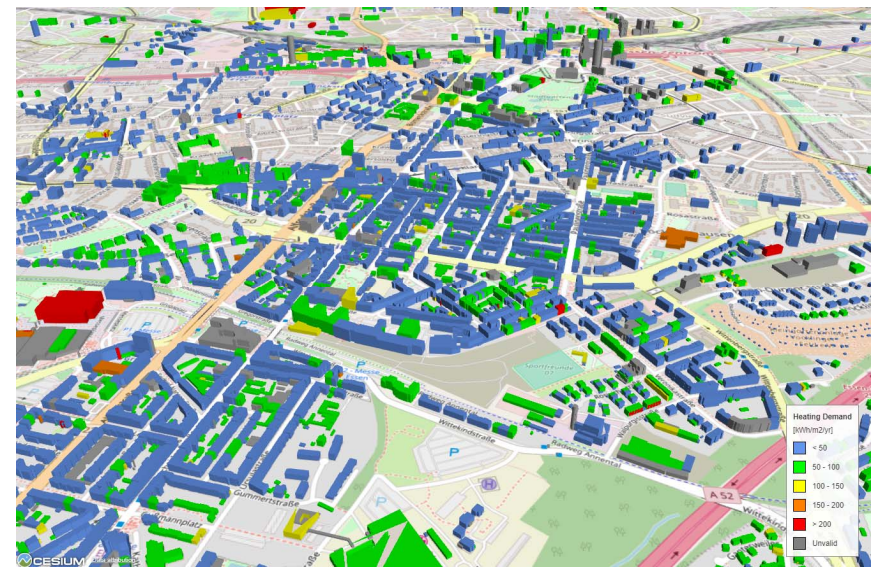

Fig. 6. City of Essen heating consumption with Advanced Refurbishment.

\section{CitySim engineering tool: A district of Geneva}

A sample CityGML dataset has been extracted from the cadaster data from the city of Geneva covering a part of the Jonction district. Coupled with statistical data taken from the Federal Register of Building and Dwellings, a CitySim simulation was realized for both the $2.5 \mathrm{D}$ and $3 \mathrm{D}$ geometrical representations.

The resulting space heating consumptions were inserted in a PostgreSQL database permitting the use of standard GIS tools to create maps and statistics (Fig. 7). The covered zone consumes about $156 \mathrm{GWh} / \mathrm{y}$ for its heating purposes under the TMY climate.

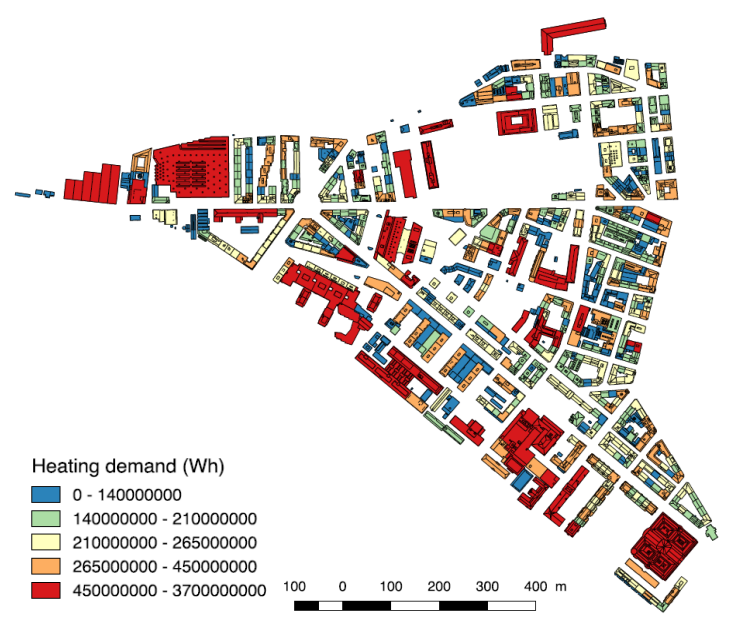

Fig. 7. Space heating consumption of the part of the Jonction district simulated with CitySim under the TMY climate.

Refurbishment scenarios were evaluated under the 2030 and 2050 climates foreseen by the Swiss meteorological office. Fig. 8 shows the heating consumptions that can be achieved by a good (triple glazing) and best retrofit (triple glazing and efficient envelope) of the buildings in the neighborhood together with the PV generation potential on the roofs of the buildings. Such simulations may be useful for urban planners and decision makers in urban areas to achieve energy efficiency within the built environment, reducing the greenhouse gas emissions in the atmosphere. 


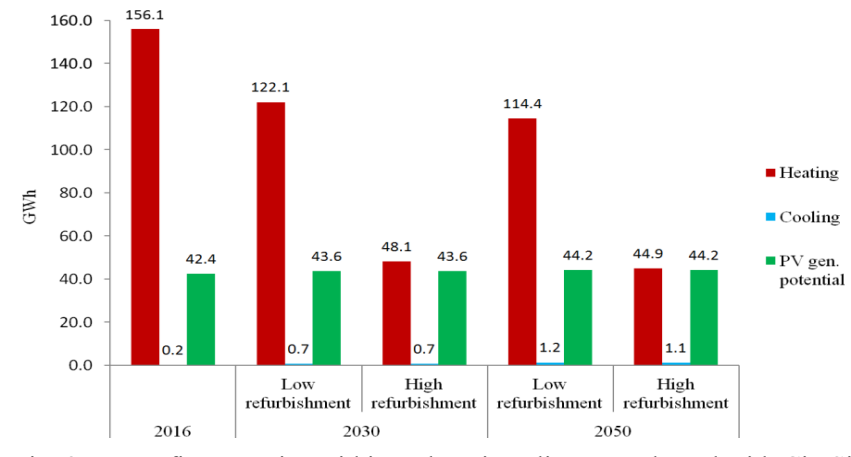

Fig. 8. Retrofitt scenarios within a changing climate evaluated with CitySim.

V.

CONCLUSIONS

The use of energy models on an urbane scale are useful to evaluate how policies for the energy efficiency retrofit of existing buildings and a more use of renewable energy technologies could impact on energy security and sustainability in future years. The high-density anthropic activity in urban environments causes also air pollution levels far above the limits about air quality concentrations, with consequences on the heath of citizens and the livability of the city. The adoption of energy use models at territorial scale can then test and drive energy and environmental policies for a sustainable development of the critical urban areas.

The main objective of this work was to compare three different models to analyse the energy performance of buildings and to find a simplified assessment to manage data and to represent the spatial distributions of buildings with their energy consumptions and GHG emissions.

The European Directive Inspire may propose the standard CityGML to facilitate the data exchange between databases and application software tools with the aim of characterizing the energy performance of buildings; CityGML was also chosen for its user-friendly 3D representation. Perhaps, any tool and platform could be used for the exchange and representation of data if the obtained results have a certain accuracy. The scale with which data are provided is very important for this purpose.

In this work, the application of three energy performance models using a GIS-base assessment, a CityGML tool and the engineering tool CitySim were analysed on three case studies, respectively: Turin, Essen and Geneva.

A possible future research is to use a $3 \mathrm{D}$ model and Simstadt to generate input data for the GIS based approach; engineering methods, as CitySim, will be also used to generalize the results to different urban contexts and climates.

\section{ACKNOWLEDGMENT}

This research collaboration was supported by the Project UNTITLED co-financed by DIST of Politecnico di Torino.

\section{REFERENCES}

[1] UNEP. The Emissions Gap Report, 2017, wedocs.unep.org/bitstream/handle/20.500.11822/22070/EGR_2017.pdf (avalilable at August 2018).

[2] World Energy Council, World Energy Issues Monitor - Conseil Mondial de l'Énergie for sustainable Energy, 2015.

[3] International Energy Agency, Energy Efficiency Indicators Highlights, 2017, webstore.iea.org/energy-efficiency-indicators-2017 highlights (avalilable at August 2018).
[4] Mutani, G., and Todeschi, V. 2017. Space heating models at urban scale for buildings in the city of Turin (Italy). Energy Procedia, 122, 841-846. doi: 10.1016/j.egypro.2017.07.445.

[5] Nouvel, R., Schulte, C., Eicker, U., Pietruschka, D., Coors, V. 2013, August 26-28. CityGML-based 3D City Model for Energy Diagnostics and Urban Energy Policy Support. 13 ${ }^{\text {th }}$ International Conference of the International Building Performance Association, pp. 218-225, France.

[6] Mutani, G., Todeschi, V., Guelpa, E., Verda V. 2017. Buildings energy efficiency hypothesis and the optimization of the district heating network. $10^{\text {th }}$ International Conference on Improving Energy Efficiency in Commercial Buildings and Smart Communities, Frankfurt, in press.

[7] Nouvel, R., Zirak, M., Dastageeri, H., Coors, V., Eicker, U. 2014. Urban energy analysis based on $3 \mathrm{D}$ city model for national scale applications. In Proceedings BauSIM 2014, September 22-24, 2014, RWTH Aachen.

[8] Koukofikis, A., Coors, V. 2015. An Integration of Urban Spatial Data with Energy Simulation to Produce X3D City Models: The case of Landkreis Ludwigsburg, Proceedings of $20^{\text {th }}$ International Conference on 3D Web Technology, 101-105, 10.1145/2775292.2775325.

[9] Wienke, U. 2002. L'edificio passivo. Standard, requisiti, esempi, Vol. 61, Alinea Ed., ISBN 8881256274, pp 192 (in Italian).

[10] Mutani, G., and Vicentini, G. 2015. Buildings' energy consumption, energy savings and the availability of Renewable energy sources in urban contexts: the potential of GIS tools. Journal of Civil Engineering and Architecture Research, Vol. 2 (11), ISSN 2333-9128, 1102-1115.

[11] Carozza, M., Mutani, G., Coccolo, S., Kaempf, J.H. 2017. Introducing a hybrid energy-use model at the urban scale: the case study of Turin (IT). $3^{\text {rd }}$ Building Simulations Application Conference BSA 2017, Bolzano.

[12] Nouvel, R., Brassel, K., Bruse, M., Duminil, E., Coors, V., Eicker, U., Robinson, D. 2015. SimStadt, a new workflow driven urban energy simulation platform for CityGML city models, International Conference Future Buildings and Districts, CISBAT, EPFL Lausanne, 889-894.

[13] Coors, V., Bruse, M., Nouvel. R. 2015. Heating Demand Calculation of build stock based on 3D City Models using SimStadt, HFT Stuttgart, University of Applied Sciences, Schellingstr. 24, 70174 Stuttgart (DE).

[14] Monien, D., Strzalka, A., Koukofikis, A., Coors, V., Eicker, U. 2017. Comparison of building modelling assumptions and methods for urban scale heat demand forecasting, Future Cities and Environment 3:2, DOI10.1186/s40984-017-0025-7.

[15] Nouvel, R., Zirak, M., Coors, V., and Eicker, U. 2017. The influence of data quality on urban heating demand modeling using 3D city models, Computers, Environment and Urban Systems, Vol. 64, 68-80, ISSN 0198-9715, doi 10.1016/j.compenvurbsys.2016.12.005.

[16] Kämpf, J.H., Robinson., D. 2007. A Simplified Thermal Model to Support Analysis of Urban Resource Flows. Energy and Buildings 39(4):445- 53. doi 10.1016/j.enbuild.2006.09.002.

[17] Mauree, D., Coccolo, S., Kämpf, J.H., and Scartezzini, J.L. 2017. Multiscale modelling to evaluate building energy consumption at the neighbourhood scale, in PLoS ONE, vol. 12, num. 9, p. e0183437.

[18] Kämpf, J.H., M. Montavon, J. Bunyesc, R. Bolliger, D. Robinson. 2010. Optimization of buildings' solar irradiation availability. Solar Energy 84: 596-603. doi: 10.1016/j.solener.2009.07.013.

[19] Bruse, M., Nouvel, R., Wate, P., Kraut, V., and Coors, V. An Energyrelated CityGML ADE and its Application for Heating Demand Calculation, International Journal of 3-D Information Modeling (IJ3DIM) 4(3), IGI GLobal, 59-77, doi 10.4018/IJ3DIM.2015070104.

[20] Amt für Stadtplanung und Bauordnung, Update of the Building File of the city Essen, April 2018, www.essen.de/rathaus/statistik/Statistik_Wohnen_u._Bauen.de.html.

[21] Mutani, G., Todeschi, V. 2018. Energy Resilience, Vulnerability and Risk in Urban Spaces, Journal of Sustainable Development of Energy, Water and Environment Systems, doi: https://doi.org/10.13044.

[22] Guelpa, E., Mutani, G., Todeschi, V., Verda V. 2017. A feasibility study on the potential expansion of the district heating network of Turin. Energy Procedia, 122, 847-852. doi: 10.1016/j.egypro.2017.07.446.

[23] Monien, D., Strzalka, A., Koukofikis, A., Coors, V., and Eicker, U. 2017. Comparison of building modelling assumptions and methods for urban scale heat demand forecasting, Future Cities and Environment 3:2, Springer, DOI10.1186/s40984-017-0025-7.

[24] Amt für Statistik, Stadtforschung und Wahlen, Evaluations of the population file of the city Essen, June 2018, www.essen.de/rathaus/statistik/Statistik_Bevoelkerung.de.html.

[25] Mutani, G., Cristino, V., Bullita, M. 2018. The urban heat island of the Metropolitan City of Turin. Strategies for a sustainable urban planning, Proceedings of the XXIII A.I.P.T. Conference 2017, Turin, in press. 